\title{
Effects of Service Quality Management on Performance of Vernacular Radio Broadcasting Firms in Western Kenya
}

\author{
Beatrice Akoth Awino, PhD Student \\ Charles Omondi Ondoro, Lecturer \\ Beatrice Evelyn Abong'o, Lecturer \\ Maseno University, Department of Business Administration, Kenya
}

Doi:10.19044/esj.2018.v14n25p216 URL:http://dx.doi.org/10.19044/esj.2018.v14n25p216

\begin{abstract}
Managing the quality of products and services is very important in ensuring that business excels in meeting its customer requirements and achieves organizational goals. Recent studies around service quality management cover quality management and total quality management in various contexts. However, knowledge on effect of service quality management on performance of vernacular radio firms is lacking. This study explored the effect of service quality management on performance of vernacular radio broadcasting firms in western Kenya. The study adopted explanatory research design on 16 vernacular radio stations from the western region of Kenya covering the Nyanza and Western Counties. Primary data was collected and analysed descriptively. The study revealed that service quality management positively and significantly predicts performance of vernacular radio broadcasting firms in Western Kenya $(\beta=0.839, \mathrm{p}<0.05)$. The regression weight value of 0.839 implies that an increase of 1 standard deviation in the management of service quality is likely to lead to an increase of 0.839 standard deviations in performance of vernacular radio broadcasting firms. The study concluded that service quality management has a positive and significant effect on the performance of vernacular radio broadcasting firms in western Kenya, and accounts for up to $70.4 \%$ of the variation in firm performance.
\end{abstract}

Keywords: service quality management, Performance, Total Quality Management

\section{Introduction}

Service quality can be perceived as the result of customers' comparison of their expectations about a service and their perception of the way the service has been performed (Gronross, 1984; Caruanaet al; 2000). 
Further, when all service quality features such as tangibility, responsiveness, empathy, assurance and reliability are effectively implemented; it may result in enhanced satisfaction of service clients (Gronross, 1984, Parasuramanet.al 1988; Azman, 2009). Service quality is the extent to which a firm successfully serves the purpose of the customer (Zeithaml, Parasuraman and Berry, 1990). The sum total of customer's expectations, service delivery process and service outcome will have an influence on service quality. Moreover, Edvardsson (2005) note that service quality perception is formed in the process of production, delivery and service consumption. Furthermore, prior experience with a particular service will largely influence the extent of their customer perceptions of service quality (O’Neill and Palmer, 2003).

\section{Literature Review}

Pignanelli \& Csillag (2008) investigated the impact of quality on profitability, following the evolution during a ten years period of 31 firms recognized by Brazilian National Quality Award (PNQ). Data of other companies from the same sectors were also considered, reaching 5354 observations. The statistical analyses included regressions, parametric and non-parametric analyses. The main finding was the lack of evidence of improved profitability in Brazilian companies that adopted quality management, when comparing the period before and after being recognized by the FNQ.

Mose and Kibera (2015) empirically assessed the influence of service quality management practices (top management support, employee management, customer orientation, quality information, reward and recognition and product/service) on the performance of hotel firms in Kenya. The pertinent hypothesis was derived from the objective. The study population comprised 209 hotel firms registered with the Kenya Association of Hotelkeepers and Caterers (KAHC) which is the principal umbrella body that brings together duly registered hotels, lodges, restaurants, membership clubs and camps operating in Kenya. A descriptive cross-sectional survey was used. The relevant primary data were collected from Chief Executives and Senior Managers using semi-structured questionnaire. Data were analyzed using descriptive statistics, inferential statistics and regression analysis. The results of the study revealed that service quality management practices significantly influences performance. The coefficient of determination $\left(\mathrm{R}^{2}\right)$ showed that service quality management practices explained $14.8 \%$ of the variation in overall firm performance. Holding other factors constant, a unit increase in service quality practices would cause a 0.359 increase in firm performance. A $\mathrm{t}$-value of 3.857 was established at $\mathrm{p}=0.000$ depicting that the relationship was statistically significant at $95 \%$ confidence level (p-value $<.05$ ). 
Munyao (2014) determined the extent of adoption of service quality management practices by petroleum distributing firms in Kenya, the challenges they face in the implementation of these practices and the effect of these practices on the firms' operational performance. The study was carried out through a descriptive survey of 32 petroleum distributing firms in Kenya. Questionnaires were used to collect primary data. The collected data was analyzed descriptive statistics while regression analysis technique was used to establish the relationship between the dependent and independent variables. The findings indicated that petroleum distributing firms adopted various service quality management practices to a large extent. The findings also indicated that lack of visionary leadership and top management support were the biggest challenges the firms faced in their endeavor to implement service quality management practices (SQMP). Further, the relationship between the explored seven aspects of SQMP and operational performance was found to be weak due to the fact that some control variables like size of the firm and number of years in operation were not considered

Kerubo (2015) examined the extent of adoption of service quality management by shipping agents in Kenya and analysed the relationship between service quality management and performance of shipping agents in Kenya. The study was carried out through a descriptive survey of 29 Shipping Agency Firms in Kenya. Questionnaires were used to collect primary data. The collected data was analysed using descriptive statistics while regression analysis technique was used to establish the relationship between the dependent and independent variables. The research findings were presented in tables and a pie chart. The findings indicated that Shipping Agents adopted Customer Focus as a major service quality management practices compared to other practices; top management support, employee management, process management, system process, continuous improvement, rewards and recognition. Further, the study depicted a statistically positive significant relationship between service quality management practices and performance of Shipping Agents in Kenya.

Cheng' \& Lin (2014) discussed the relations between Service Quality and Organizational Performance with a quantitative questionnaire survey. The employees and consumers of De-yi Chinese Food Company were sampled for the survey, in which total 300 copies of questionnaires are distributed and 233 effective copies are retrieved. Service Quality is regarded as the independent variable, Organizational Performance as the dependent variable, and demographic variable as the moderator to discuss the correlations. The data were analyzed with Regression Analysis and Analysis of Variance for the following research conclusions. (1) Service Quality presents partially positive effects on Financial Performance in Organizational Performance. (2) Service Quality shows partially positive effects on Operating Performance in 
Organizational Performance. (3) Service Quality reveals partially positive effects on Behavioral Performance in Organizational Performance. (4) The correlation between Service Quality and Organizational Performance appears remarkable differences in demographic variables

Liew \& Yean. (2009) examined the relationship between service quality and market orientation and their impact towards organizational performance. A total of 175 sets of questionnaires were distributed to the employees of the selected organizations in Kuching, and 92\% of it, which is 161, was returned. The results showed that service quality has a significant effect on organizational performance and market orientation. Market orientation also has a significant effect on organizational performance. The study also found that market orientation moderate the relationship between service quality and organizational performance. There is still a shortage of research studying the impact of market orientation as a moderator on the relationship between service quality and organizational performance.

Wanyoike (2016) studied effect of quality management practices on performance of manufacturing firms in Kenya. The specific objectives were: To establish the effect of continuous improvement on firm performance; to assess the influence of customer focus on firm performance; to determine the extent to which top management commitment affects the performance of manufacturing firms in Kenya; to assess the extent to which the operating environment moderates the relationship between quality management practices and the performance of manufacturing firms in Kenya; and to establish the mediating effect of organizational capability on the relationship between quality management practices and performance. The target population comprised all 60 manufacturing firms in Kenya and a sample size of 120 respondents. The study adopted census sampling technique. The study used primary data which was collected using self-administered questionnaires. The findings indicate that continuous improvement had positive and significant effect on performance of manufacturing firms. Customer focus was found to be significant in explaining the variation of performance and top management commitment was found to have a significant effect of performance of manufacturing firms. Organizational capability had a partial mediating effect on the relationship between quality management practices and performance. Operating environment had a moderating effect on the relationship between quality management practices and performance.

Nilsson, Johnson \& Gustafsson (2016) analyzed and investigated how key internal quality practices of product versus service organizations (employee management, process orientation, and customer orientation) influence customer satisfaction and business results. Using a national quality survey from 482 companies in Sweden, the analysis showed that for product organizations, internal quality practices influence customer satisfaction and 
business results primarily through an organization's customer orientation. For service organizations, both customer and process orientation impact customers directly, and employee management has a direct impact on business results. The research also supports the claim that organizations with a quality foundation are in a better position to adopt a customer orientation.

Ntongai, Ojera and Ochieng (2015) sought to establish the effects of service quality practices on satisfaction levels of mobile phone subscribers in Kenya. The study used a proportionate stratified sampling technique to select a sample of 384 respondents on a population of 32.2 million subscribers. The study finding revealed that the R2 for service quality practices was 0.609 , $\mathrm{p}<05$, indicating that service quality practices account for $60.9 \%$ of variance in the customer satisfaction among mobile phone firms in Kenya.

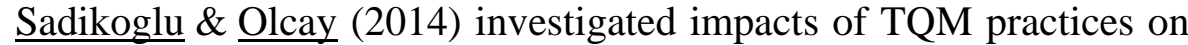
various performance measures as well as the reasons and the barriers of the TQM practices of firms in Turkey. A cross-sectional survey methodology was used, and the unit of the sample was at the plant level. The sample was selected from the member firms to Turkish Quality Association and the firms located in the Kocaeli-Gebze Organized Industrial Zone. They obtained 242 usable questionnaires, with a satisfactory response rate of 48.4 percent. They conducted exploratory factor analysis and multiple regression analysis. The study has showed that different TQM practices significantly affect different performance outcomes. Results revealed that primary obstacles that the firms in Turkey face were lack of employee involvement, awareness and commitment of the employees, inappropriate firm structure, and lack of the resources.

Chepkech (2014) examined the effect of Total Quality Management practices on organizational performance in Kenya. The specific objectives of this study were to determine the effect of top management commitment on organizational performance, to investigate the effect of customer focus on organizational performance and to examine the effect of employee involvement on organizational performance. It adopted explanatory research design. The target population comprised head of departments and tutors in the tertiary institutions within UasinGishu County whose total population was 421 . The sample size of 264 respondents was drawn using stratified random sampling. Questionnaires were used to collect primary data. Pearson correlation was used to determine the relationship between the total quality management practices and organizational performance while multiple regressions were used to determine the effects of the various elements of total quality management on organizational performance. The study findings of correlation analysis showed that top management commitment, employee involvement, and customer focus were positively and significantly affect organizational performance. The findings of the multiple regressions analysis 
showed that the observed changes in organizational performance attributed to the elements of total quality management practice is $56.9 \%(\mathrm{r} 2=.569)$. This finding of this research supports the hypothesis that total quality management practices significantly affect organizational performance thus any tertiary institution managers aiming to achieve organizational performance should pay close attention to all the elements of total quality management. The study recommends that future studies test the effects of the other elements of total quality management practices on organizational performance that were not part of the current study.

While Liew \& Yean (2009) examined the relationship between service quality and market orientation and their impact towards organizational performance, Wanyoike (2016) on the other hand studied effect of quality management practices on performance of manufacturing firms in Kenya. Far from these Sadikoglu \& Olcay (2014) investigated impacts of TQM practices on various performance measures as well as the reasons and the barriers of the TQM practices of firms in Turkey. It is also noted that Chepkech (2014) examined the effect of Total Quality Management practices on organizational performance in Kenya while Kerubo (2015) examined the extent of adoption of service quality management by shipping agents in Kenya and analyzed the relationship between service quality management and performance of shipping agents in Kenya. Munyao (2014) equally looked at the extent of adoption of service quality management practices but in petroleum distributing firms in Kenya, the challenges they face in the implementation of these practices and the effect of these practices on the firms' operational performance. Whereas Mose and Kibera (2015) empirically assessed the influence of service quality management practices (top management support, employee management, customer orientation, quality information, reward and recognition and product/service) on the performance of hotel firms in Kenya, Cheng' \& Lin (2014) on the other hand discussed the relations between Service Quality and Organizational Performance with a quantitative questionnaire survey. Ntongai, Ojera and Ochieng (2015) added a lone voice to the debate by studying customer satisfaction as an outcome of service quality management.

From the above studies it is observed that the researchers concentrated their studies on customer satisfaction, service quality management practices, total quality management and adoption of service quality. They investigated these on various levels of organizational performance. Service quality management among media firms is unclear. Therefore, this knowledge is also lacking among media industry firms with radio firms included. For those who investigated service quality management their works were limited to individual areas of firm performance and those who covered service quality management and firm performance did so in different context for instance petroleum distribution firms and shipping agents. Operations of these firm are different 
from those of radio broadcasting firms. Therefore, knowledge on effect of service quality management on performance of vernacular radio broadcasting firms is lacking.

\section{Methods}

The study relied solely on primary data collected at first hand from the identified managerial staff. Primary data was collected from primary sources that provided data that relates to the object of study (Galvan, 2013). Questionnaires were, developed for purposes of gathering data from these primary sources. On the basis of positivist paradigm, the study adopted explanatory research design on 16 vernacular radio stations drawn from the western region of Kenya covering the Nyanza and Western Counties. It is argued that explanatory research also called causal research is conducted for purposes of identifying the extent and nature of cause-and-effect relationships (Gelman, 2011), Primary data was collected from the identified managerial staff, and analysed descriptively by use of means and standard deviations to explore the prevailing status of the study variables in vernacular radio broadcasting firms in western Kenya.

A model for regression of firm performance on service quality management

$$
V R F P=\beta_{0}+\beta_{4} S Q M+\varepsilon
$$

Where;

$V R F P \Rightarrow$ Vernacular radio firm performance

$S Q M \Rightarrow$ Service quality management

$\varepsilon \Rightarrow$ Residuals

\section{Findings}

The study hypothesis postulated that service quality management had no effect on performance of vernacular radio broadcasting firms in western Kenya. To test this hypothesis, a regression of firm performance on service quality management was conducted. The model summary of this regression as shown in Table 4.18 highlights the fact that service quality management has a direct effect on the performance of vernacular radio broadcasting firms in western Kenya and accounts for up to $70.4 \%$ of the variance in firm performance.

Table 1.0 Model Summary of Regressing Firm Performance on Service Quality Management

\begin{tabular}{cccccc}
\hline \hline Model & $\mathrm{R}$ & R Square & Adjusted R Square & Std. Error of the Estimate & Durbin-Watson \\
1 & $.839^{\mathrm{a}}$ & .704 & .701 & .28892 & 1.973 \\
\hline \hline
\end{tabular}

a. Predictors: (Constant), Service quality management

b. Dependent Variable: Firm performance 
In addition, the ANOVA results displayed in Table 1.0 endorses the hypothesized model relating firm performance with service quality management as being statistically viable $\left(\mathrm{F}_{1,105}=249.646, \mathrm{p}<0.05\right)$.

Table 1.1 ANOVA for Regressing Firm Performance on Service Quality Management

\begin{tabular}{llllll}
\hline \hline Model & Sum of Squares & Df & Mean Square & F & Sig. \\
$1 \quad$ Regression & 20.839 & 1 & 20.839 & 249.646 & $.000^{\mathrm{b}}$ \\
$\quad$ Residual & 8.765 & 105 & .083 & & \\
$\quad$ Total & 29.604 & 106 & & & \\
\hline \hline
\end{tabular}

a. Dependent Variable: Firm performance

b. Predictors: (Constant), Service quality management

The standardized regression weight (coefficient) provided in Table 1.1 affirms that service quality management positively and significantly predicts performance of vernacular radio broadcasting firms in Western Kenya ( $\beta=$ $0.839, \mathrm{p}<0.05)$. The regression weight value of 0.839 implies that an increase of 1 standard deviation in the management of service quality is likely to lead to an increase of 0.839 standard deviations in performance of vernacular radio broadcasting firms.

Table 1.2 Effect of Service Quality Management on Firm Performance

\begin{tabular}{lcccccc}
\hline \hline Model & \multicolumn{7}{c}{$\begin{array}{c}\text { Unstandardized } \\
\text { Coefficients }\end{array}$} & $\begin{array}{c}\text { Standardized } \\
\text { Coefficients }\end{array}$ \\
1 & B & Std. Error & Beta & $\mathbf{t}$ & Sig. \\
& (Constant) & .724 & .234 & & 3.090 & .003 \\
& $\begin{array}{c}\text { Service quality } \\
\text { management }\end{array}$ & .873 & .055 & .839 & 15.800 & .000 \\
\hline \hline
\end{tabular}

a. Dependent Variable: Firm performance

Source: Survey data, 2018

The results confirm that the management of service quality remains a central criterion in performance of vernacular radio broadcasting firms. By managing the quality of the services they render; the firms have a chance to up their performance. Indeed, the finding that service quality management positively and significantly impacts on firm performance supports a plethora of studies in extant literature, and raises some pertinent issues.

Mose and Kibera (2015) for instance, report that use of diverse service quality management practices significantly and positively influences firm performance. However, the study by Mose and Kibera indicates that service quality management accounts for only up to $14.8 \%$ of variations in firm performance. The finding in the present study on the contrary shows that service quality management accounts for up to $70.4 \%$ of firm performance. The difference in the contributions of service quality in the two studies raises concerns. However, considering that Mose and Kibera's study was conducted in the hotel industry, it would appear that the context under which the study is 
undertaken may have some influence on the manner in which service quality management impacts firm performance. Future studies should therefore look to allay such conjectures by controlling for the influence of the context.

The finding showing that service quality management has positive and significant effects on performance of vernacular radio broadcasting firms fills a major void that has hitherto existed in literature, particularly in the Kenyan context. Previous studies in Kenya, have attributed service quality management to improved performance of firms in shipping agencies Kerubo, 2015); manufacturing firms (Wanyoike, 2016); mobile phone industry (Ntongai, et al, 2015); tertiary institutions (Chepkech, 2014); and hotel industry (Mose\&Kibera, 2015). The present study therefore expands the scope of the impact of the management of service quality on improved performance of firms in the radio broadcasting industry.

The finding of this study with regards to the impact of service quality management on firm performance however contradicts findings by Pignanelli and Csillag (2008). The two authors lacked evidence to back the claim that Brazilian companies that adopted quality management showed an improvement in profitability. These contradictory results are rather interesting but go to show that generalization of findings on studies focusing on quality management and firm performance need to be sensitive to the context within which studies are conducted. As a cautionary measure, it is prudent to note that service quality management practices have been found to have varying impacts on firm performance (Sadikoglu \& Olcay, 2014).

\section{Conclusion}

The study objective sought to establish the effect of service quality management on the performance of vernacular radio broadcasting firms in western Kenya. Descriptive exploration of key informants' response scores revealed that service quality is very highly prioritized in the sampled firms. This is mainly in form of accurate reporting; building trust with customers; offering diverse packages; timely and fast delivery of services; and taking into consideration customer preferences.

The regression results revealed that service quality management has a positive and significant effect on the performance of vernacular radio broadcasting firms in western Kenya, and accounts for up to $70.4 \%$ of the variation in firm performance. The implication is that the study was able to affirm that despite service quality management being considered as a moderator in the present study, it on the contrary also has direct effects on firm performance. Consequently, it remains a crucial facet of the performance of vernacular radio broadcasting firms.

The implication of these results is that in recognition of service quality as precursors to firm performance, vernacular radio broadcasting firms in 
western Kenya have put in place several mechanisms through which to manage quality of products and services. This is indeed consistent with the views advanced by Perez et al., (2007) that service quality management is integral to the management of both customer and business growth. These results in essence show that radio broadcasting firms combine both empathy and tangibles approaches in ensuring quality in their services. The bottom line is that besides high application of market challenger strategies, the firms have also opted to invest heavily on service quality.

\section{Recommendations}

Service quality management is given priority among vernacular radio broadcasting firms in western Kenya. Besides designing products and services by factoring in customer preferences, firms also look for fast and timely delivery of services. This definitely portends well considering that service quality management impacts positively on firm performance. Service quality management appears to have different effects on firm performance in different contexts, which tends to suggest that perhaps the context of study could be a factor.

\section{References:}

1. Cheng, S-J. \& Lin, Y-C. (2014) Effects of service quality on organizational performance. Pakistan Journal of Statistics, 30(6), 1131-1140.

2. Grönroos, C. (1984), “A Service Quality Model and its Marketing Implications", European Journal of Marketing, 12, (8), pp.588-600

3. Grönroos, C. (2000), Service Management and Marketing - A Customer Relationship Management Approach, 2nd Edition, John Wiley and Sons Ltd

4. Liew, S. Y., (2009). The impact of service quality on organizational performance. Does market orientation matter? [Project Report] (Unpublished)

5. Mose, J.A. \&Kibera, F.N. (2016). The influence of service quality management practices on the performance of hotel firms in Kenya. European Scientific Journal 11(22), 315-332.

6. Munyao, S. M., (2014). Effect of service quality management practices on operational performance of petroleum distributing firms in Kenya. http://erepository.uonbi.ac.ke

7. Ntongai, S.J.,Ojera, P.B.,\& Ochieng, I.O.(2015). Service quality practices as a critical antecedent to customer satisfaction evidence from Kenya's mobile phone sector. International Journal of Economics, Commerce and Management, III(12), 160-173. 
8. Pignanelli, A. Csillag, J.M., (2008). The impact of quality management on profitability: An empirical study. The Flagship Research Journal of International Conference of the Production and Operations Management Society Volume 1(1), 66-77

9. Wanyoike, R.W., (2016). Quality management practices and firm performance among manufacturing firms in Kenya. http://irlibrary.ku.ac.ke/bitstream/handle 